\title{
PENGARUH TINGKAT SUKU BUNGA (BIRATE) DAN KURS DOLAR AS TERHADAP \\ INDEKS HARGA SAHAM GABUNGAN (IHSG) DENGAN MENGGUNAKAN METODE ERROR CORECTION MODEL (ECM)
}

\author{
Oleh: \\ Muhammad Mahdi \\ Badan Perencanaan Pembangunan Daerah (BAPPEDA) Kab. Hal-Sel Maluku Utara \\ E-mail/No. Hp: mehdy_hebsy@yahoo.co.id/08123528052 \\ David Kaluge \\ Fakultas Ekonomi Universitas Brawijaya Malang \\ E-mail/No. Hp: dkaluge@yahoo.com/ -
}

\begin{abstract}
This research to determine whether, exchange rate, interest rate (BI Rate) have an influence on Indeks Harga Saham Gabungan (IHSG). The data used are secondary data from the period June 2008 to August 2010. The analytical tool used in this research is the error correction model (ECM). Previously conducted tests stasioneritas namely the root of the test unit and test the degree of integration and cointegration tests. Based on the test stasioneritas obtain stationary data on a Zero level at a significance level of $10 \%$ and other data on the first level and terkointegrasi diffirence on the zero level at 1\% level of significance. The result of an error correction model analysis showed that in short term interest rate (BI Rate), Ezchange rate, significantly influences the IHSG fluctuates, while the long-term variable Exchange rate has a significant while variable interest rate is not significant.
\end{abstract}

Keywords: IHSG, interest, rate, and error correction model

\section{PENDAHULUAN}

Di era globalisasi ini, hampir semua negara menaruh perhatian besar terhadap pasar modal karena memiliki peranan strategis bagi penguatan ketahanan ekonomi suatu negara. Terjadinya pelarian modal ke luar negeri (capital flight) bukan hanya merupakan dampak merosotnya nilai rupiah atau tingginya inflasi dan rendahnya suku bunga di suatu negara, tetapi karena tidak tersedianya alternatif investasi yang menguntungkan di negara tersebut, atau pada saat yang sama, investasi portofolio di bursa negara lain menjanjikan keuntungan yang jauh lebih tinggi. Keadaan ini terjadi sebagai konsekuensi dari terbukanya pasar saham terhadap investor asing.

Pasar modal yang ada di Indonesia merupakan pasar yang sedang berkembang (emerging market) yang dalam perkembangannya sangat rentan terhadap kondisi makroekonomi secara umum. Krisis ekonomi yang dimulai ahun 1998 merupakan awal runtuhnya pilar-pilar perekonomian nasional Indonesia. 


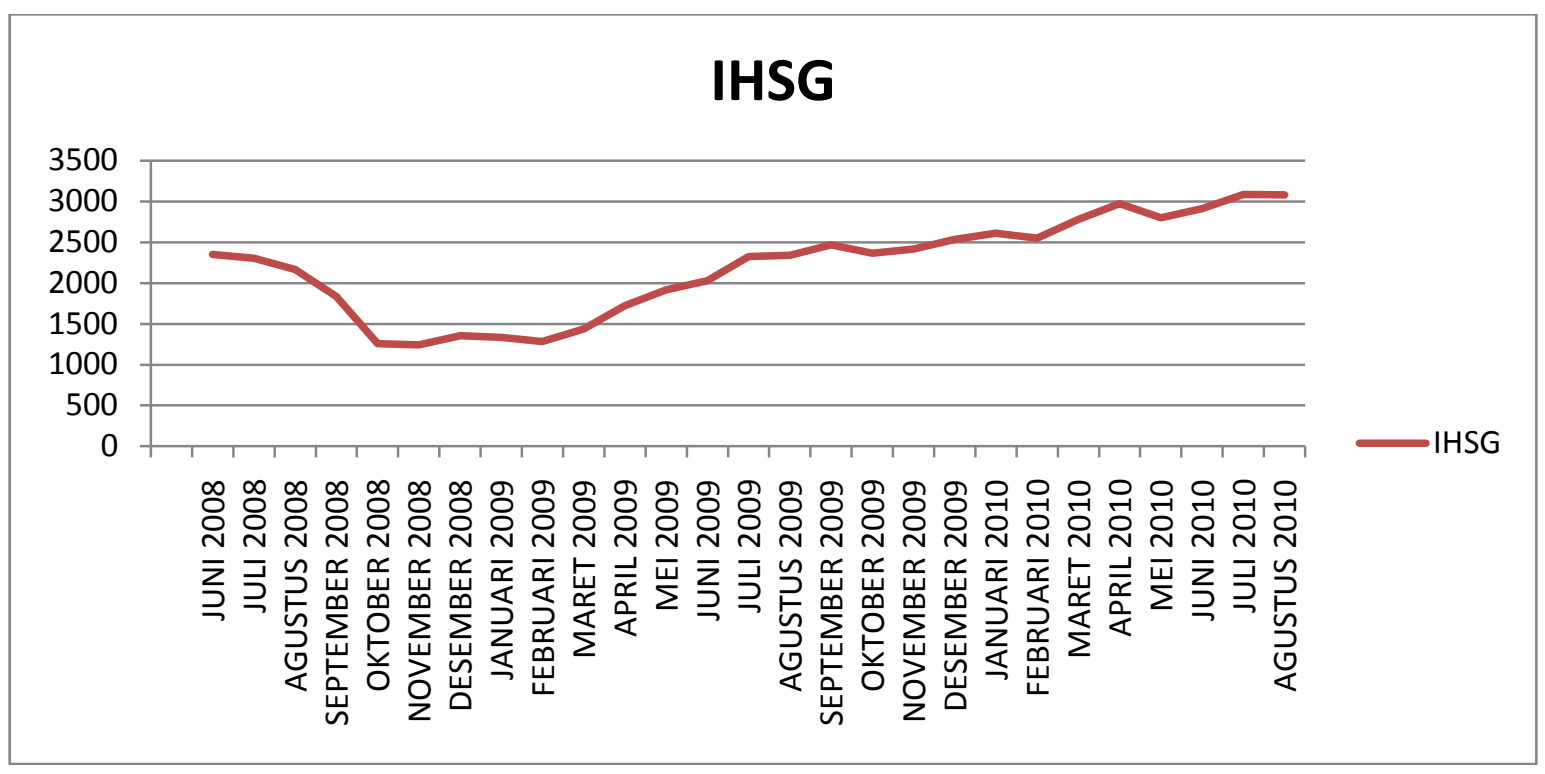

Gambar 1. Grafik perkembangan IHSG periode Juni 2008- Agustus 2010

Sumber:IMQ indostocq (data diolah)

Hal ini ditandai dengan turunnya kepercayaan masyarakat terhadap perbankan Indonesia dalam bentuk penarikan dana besar-besaran (rush) oleh deposan untuk kemudian disimpan di luar negeri (capital flight). Tingkat suku bunga yang mencapai $70 \%$ dan depresiasi nilai tukar rupiah (kurs) terhadap dolar AS sebesar $500 \%$ mengakibatkan hampir semua kegiatan ekonomi terganggu. Dampak lain dari menurunnya kepercayaan masyarakat berimbas sampai ke pasar modal. Hargaharga saham menurun secara tajam sehingga menimbulkan kerugian yang cukup signifikan bagi investor. Bagaimana tidak, jika saham yang dijual dengan harga hanya Rp 10,- per lembar dan Indeks Harga Saham Gabungan (IHSG) pernah turun sampai di bawah 300.

Namun, bila melihat indikator ekonomi beberapa tahun terakhir ini, gejala pemulihan kepercayaan masyarakat mulai tampak. Pada Oktober 2008, IHSG mencapai 1256.699 dan sampai Desember 2009 telah mencapai 2534.355. Ini merupakan peningkatan yang cukup signifikan mengingat IHSG pada tahun 2004, 2005 , baru mencapai 820,1 dan , 1162,63,. Kemudian sepanjang periode bulan Januari-Agustus 2010, PT Bursa Efek Jakarta (BEJ) terus menerus berupaya menciptakan pasar yang semakin likuid, wajar, teratur dan transparan. Sepanjang periode di atas, bursa telah menunjukkan prestasi yang sangat menggembirakan. Salah satunya ditunjukkan dengan Indeks Harga Saham Gabungan (IHSG) BEJ yang berhasil mencatat rekor tertinggi pada tanggal 1 April 2010 di level 2834,24 (www.financeindonesia.org).

\section{TINJAUAN PUSTAKA}

Dalam teori Neo Klasik dikatakan bahwa tingkat Investasi dipengaruhi oleh tingkat bunga $I=I(r)$, SBI adalah surat berharga atas unjuk dalam rupiah yang diterbitkan oleh BI sebagai pengakuan hutang berjangka waktu pendek dengan sistem diskonto. Tingkat suku bunga merupakan daya tarik bagi investor menanamkan investasinya dalam bentuk deposito atau SBI sehingga investasi dalam bentuk saham akan tersaingi. 
Menurut Cahyono (2000:117) terdapat 2 penjelasan mengapa kenaikan suku bunga dapat mendorong harga saham ke bawah. Pertama, kenaikan suku bunga mengubah peta hasil investasi. Kedua, kenaikan suku bunga akan memotong laba perusahaan. Hal ini terjadi dengan dua cara. Kenaikan suku bunga akan meningkatkan beban bunga emiten, sehingga labanya bisa terpangkas. Selain itu, ketika suku bunga tinggi, biaya produksi akan meningkat dan harga produk akan lebih mahal sehingga konsumen mungkin akan menunda pernbeliannya dan menyimpan dananya di bank. Akibatnya penjualan perusahaan menurun. Penurunan penjualan perusahaan dan laba akan menekan harga saham.

Gregory Mankiw (2007: 128) mengemukakan bahwa kurs (exchange rate) antara dua negara adalah tingkat harga yang disepakati penduduk kedua negara untuk saling melakukan perdagangan.

Terdapat dua pendekatan teori dalam melihat hubungan antara kurs dengan harga saham. Yang pertama good market approach (Dorbush \& Fisher 1980) menyatakan perubahan mata uang atau kurs mempengaruhi competiviness suatu perusahaan, yg selanjutnya mempengaruhi pendapatan atau cost of fund dan selanjutnya harga sahamnya. Dampak fluktuasi terhadap pasar modal sangat tergantung pada tingkat keterbukaan ekonomi domestic dan kesinambungan neraca perdagangan. Yang kedua adalah portofolio balance approach (Franke 1993) dimana menekankan peranan capital account transaction. Kenaikan retrun saham akan menarik capital flow yang selanjutnya akan meningkatkan demand mata uang domestic dan menyebabkan kurs mata uang terapresiasi.
IHSG merupakan cerminan dari kegiatan pasar modal secara umum. Peningkatan IHSG menunjukkan kondisi pasar modal sedang bullish, sebaliknya jika menurun menunjukkan kondisi pasar modal sedang bearish. Untuk itu, seorang investor harus memahami pola perilaku harga saham di pasar modal. Dalam penelitiannya,Lee(1992) telah ditemukan bahwa perubahan tingkat bunga (interest rate) mempunyai pengaruh yang signifikan terhadap indeks harga saham.

Sementara itu dalam artikel yang ditulis oleh Moradoglu, et al. (2000), dikemukakan bahwa penelitian tentang perilaku harga saham telah banyak dilakukan, terutama dalam kaitannya dengan variabel makroekonomi, diantaranya Chen et al. (1986), Geske and Roll (1983), dan Fama (1981). Hasil penelitian mereka mengatakan bahwa harga saham dipengaruhi oleh fluktuasi makroekonomi. Beberapa variabel makroekonomi yang digunakan antara lain; tingkat inflasi, tingkat bunga, nilai tukar, indeks produksi industri, dan harga minyak.

Ajayi dan Mougoue (1996) juga menggunakan variabel makroekonomi nilai tukar dan harga saham. Mereka meneliti hubungan dinamis antara harga saham dan nilai tukar pada "Delapan Besar" pasar saham, yaitu kanada, Perancis, Jerman, Italia, Jepang, Belanda, Inggris, dan Amerika Serikat dengan menggunakan bivariate error correction model. Hasil penelitian mereka menunjukkan hubungan yang signifikan antara nilai tukar dan harga saham (pasar modal dan pasar uang). Hasil ini kemudian didukung juga oleh Sudjono (2002) serta Sitinjak dan Kurniasari (2003) bahwa nilai tukar rupiah (kurs) mempunyai pengaruh yang signifikan terhadap IHSG. 
Selanjutnya Gupta (2000) yang mengadakan penelitian di Indonesia dengan menggunakan data periode 19931997 menyimpulkan bahwa tidak ada hubungan kausalitas antara tingkat bunga, nilai tukar, dan harga saham. Hasil ini bertolak belakang dengan Sitinjak dan Kurniasari (2003) yang menemukan bahwa nilai tukar dan tingkat bunga SBI berpengaruh terhadap IHSG. Namun Saadah dan Panjaitan (2006) kembali menunjukkan bahwa tidak ada interaksi dinamis yang signifikan antara harga saham dan nilai tukar.

Berdasarkan hasil penelitian terdahulu dimana masih menunjukkan hasil yang kontradiktif, maka peneliti tertarik untuk menelaah lebih lanjut mengenai variabel makroekonomi apakah yang sebenarnya berpengaruh terhadap IHSG.

\section{METODE PENELITIAN}

Penelitian ini akan berusaha untuk melihat hubungan antara indeks harga saham gabungan (IHSG), tingkat bunga (BI Rate) dan kurs (exchange rate). Untuk menyamakan persepsi dan memfokuskan masalah, maka disampaikan di sini bahwa data yang digunakan adalah data IHSG . Data tingkat bunga adalah tingkat bunga (Bi Rate) yang diumumkan oleh bank sentral dalam hal ini Bank Indonesia begitu juga data kurs yaitu data yang dipublikasikan oleh Bank Indonesia. sedangkan data IHSG bersumber dari IMQ indostocq. Dalam tulisan ini menggunakan data bulanan dari Juni 2008 hingga Agustus 2010. Selanjutnya dari data yang ada akan dilihat bagaimana hubungan antar variabel dalam bentuk regresi dengan pendekatan Error Correction Model (ECM).

Data yang digunakan dalam tulisan ini menggunakan data bulanan dengan alasa bahwa fluktuasi IHSG dan kurs dapat berubah tiap saat dan sangat cepat sedangkan data, Bi Rate yaitu perubahannya dilakukan tiap bulan oleh bank Sentral, sehingga cepat sekali tingkat kepekaan atas perubahan ketiganya.

Dari data yang telah didapat akan diolah dengan metode ECM. Sebelum melakukan tahapan analisis, variable IHSG dan kurs di formasikan ke dalam bentuk logaritma dulu sehingga menjadi LIHSG dan LKURS.

Langkah pertama yang perlu dilakukan untuk yaitu dengan menampilkan stasioneritas data. Uji stasioneritas data menggunakan uji unit root square yang dikembangkan oleh Dickey - Fuller, atau dikenal juga dengan nama uji ADF. Langkah yang dilakukan adalah dengan membandingkan nilai $\mathrm{t}$ statistic dengan nilai critical value-nya. Jika nilai $\mathrm{t}-$ statistic lebih besar dari nilai critical value, maka suatu variabel dikatakan stasioner.

Langkah kedua yaitu adalah dengan melihat apakah masing - masing berkointegrasi atau tidak. Dalam tulisan ini, uji kointegrasi menggunakan uji Johansen. Uji ini dilakukan dengan jalan membandingkan nilai trace statistic dengan nilai kritis pada tingkat keyakinan $5 \%$ atau $1 \%$. Jika nilai trace statistic lebih besar dibandingkan dengan nilai kritis pada tingkat $5 \%$ atau $1 \%$ maka bisa dikatakan bahwa variabel variabel tersebut berkointegrasi. Apabila variabel - variabel ternyata saling berkointegrasi, berarti ada hubungan jangka panjang (atau keseimbangan) antara variabel - variabel yang diteliti.

Selanjutnya, model koreksi kesalahan $(E C M)$ dapat diturunkan dari fungsi biaya kuadrat tunggal (single period quadratic cost function). Mengikuti pendekatan yang dikembangkan oleh Domowitz dan Elbadawi (1987) dengan terlebih dahulu 
melakukan minimisasi terhadap fungsi biaya kuadrat tunggal, akan diperoleh bentuk baku model koreksi kesalahan (ECM) yang akan digunakan sebagai model estimasi dalam penelitian ini:

Bentuk Umum model ECM.

$\mathrm{DY}_{\mathrm{t}}=\beta_{0}+\beta_{1} \mathrm{DX}+\beta_{2} \mathrm{X}_{\mathrm{t}-1}+\beta_{3} E C T+\varepsilon_{t}$

$$
\begin{aligned}
& \text { dimana: } \\
& \mathrm{Y}=\text { Variabel terikat (dependent } \\
& \text { variable) } \\
& \mathrm{X}=\text { Variabel bebas (independent } \\
& \text { variable) } \\
& D Y_{t}=Y_{t}-Y_{t-1} \\
& \mathrm{DX}_{\mathrm{t}}=\mathrm{X}_{\mathrm{t}}-\mathrm{X}_{\mathrm{t}-1} \\
& E C T=\mathrm{X}_{\mathrm{t}-1}-\mathrm{Y}_{\mathrm{t}-1}
\end{aligned}
$$

Kemudian direparameter dalam variabel Penelitian menjadi:

Dlihsg $=\beta_{0}+\beta_{1}$ Dbirate $_{\mathrm{t}}+\beta_{2}$ Dlkurs $_{\mathrm{t}}$ $+\beta_{3}$ birate $_{\mathrm{t}-1}+\beta_{4}$ lkurs $_{\mathrm{t}-1}+\beta_{5}$ ECT dimana:

$$
\text { ECT }>0 \text { dan } 0<\beta_{5}<1
$$

\section{PEMBAHASAN}

Dari olah data menggunakan eviews 4, hasil uji unit root test ditemukan bahwa variable LIHSG pada unit level atau derajat 0 atau $\mathrm{I}(0)$ dengan nilai ADF Test Statistic sebesar 3,486270 > dari nilai Cratical value pada tingkat singnifikan $10 \%$ yaitu sebesar 3,2367, sehingga variable LIHSG dikatakan Satsioner pada I (0). Sedangkan sedangkan variable LKURS dan BIRATE tidak stasioner pada tingkat level, sehingga dilakukkan pengujian unit root pada data first difference yang didapatkan hasil nilai ADF Test Statistic sebesar LKURS sebesar -4,1755910> dari nilai Cratical value pada tingkat singnifikan $1 \%$ yaitu sebesar $-2,6348$, dan BIRATE sebesar -2,124265 > dari nilai Cratical value pada tingkat singnifikan $1 \%$ yaitu sebesar -1,6231 sehingga variable LKURS dan BIRATE dikatakan Satsioner pada I (1).

Setelah diadakan uji stasioner maka dilakukkan uji kointegrasi pada variable-variabel yang tidak stasioner pada tingkatan level atau $\mathrm{I}(0)$, yaitu variable LKURS dan BIRATE. Dari hasil uji kointegrasi didapatkan hasil bahwa terdapat dua kointegrasi pada level signifikan $1 \%$ dan 5\%,hal itu dapat dilihat bahwa nilai Trace Statistic, dan nilai Max- Eigen Statistic dengan nilai kritis pada level 5\% dan 1\%, ternyata nilai Trace Statistic, dan nilai MaxEigen Statistic lebih besar dengan demikian dari hasil uji kointegrasi mengindikasikan bahwa variablevariabel tersebut mempunyai hubungan stabilitas/ keseimbangan dalam kesamaan pergerakan dalam jangka panjang., sehingga bisa dikatakan bahwa variabel yang diteliti memiliki kointegrasi.

Setelah melihat variabel yang diteliti memiliki kointegrasi maka dilakukan dengan pemodelan ECM. maka berdasarkan persamaan atau model yang telah dibuat dan diregresikan didapatkan hasil sebagai berikut:

$\mathrm{DY}_{\mathrm{t}}=\beta_{0}+\beta_{1} \mathrm{DX}_{\mathrm{t}}+\beta_{2} \mathrm{X}_{\mathrm{t}-1}+\beta_{3} E C T$

DIIHSG $=\beta_{0}+\beta_{1}$ Dbirate $_{t}+\beta_{2}$ Dlkurs $_{t}+$ $\beta_{3}$ birate $_{\mathrm{t}-1}+\beta_{4}$ lkurs $_{\mathrm{t}-1}+\beta_{5}$ ECT

$\mathrm{D}(\mathrm{LIHSG})=-12.1185-$

$$
\begin{aligned}
& 0.5036 * \mathrm{D}(\mathrm{BIRATE})+ \\
& 1.3833^{*} \mathrm{D}(\text { LKURS })+ \\
& 0.0006 * \mathrm{BIRATE}(-1)+ \\
& 1.3426 * \text { LKURS }(-1)+ \\
& 0.340)^{*} \mathrm{ECT}
\end{aligned}
$$

Dari hasil estimasi di atas, dapat dijelaskan di sini bahwa model yang coba dibangun dengan dengan ECM, dikatakan berhasil. Ini bisa diketahui dari hasil koefisien regresi ECT sebesar 0.340476 dengan nilai t-statistik sebesar 2, $379473>$ t-tabel pada $\alpha$ (level signifikan) $5 \%$ dengan derajat kebebasan (degree of freedom) n-k-1. Nilai koofisien ECT juga menunjukan kecepatan penyesuaian(speed $\mathrm{f}$ adjustment) IHSG menuju keseimbangan 
dengan nilai sebesar 0.340476 artinya bahwa sekitar 34\% ketidaksesuaian antara IHSG actual dengan IHSG yang diinginkan akan dieliminasi dalam satu periode.

Dari hasil uji $\mathrm{F}$ dapat dilihat nilai F-statistik sebesar 6,670020 > F-tabel dengan $\alpha$ (level signifikan) $1 \%$ yang menunjukan bahwa secara bersama sama variabel independen (Birate dan Kurs) mempunyai pengaruh kepada variabel dependen (IHSG). Nilai $\mathrm{R}^{2}$ dari regresi di atas menunjukkan angka $62.5 \%$ yang berarti bahwa $62 \%$ dari variasi fluktuasi IHSG dapat dijelaskan oleh variasi himpunan variabel bebasnya. Sedangkan sisanya (berkisar $38 \%$ ) fluktuasi IHSG dipengaruhi oleh variabel - variabel lainnya yang tidak dimasukkan dalam analisa ini.

Karena koefisien $\beta_{5}$ mempunyai nilai yang positif dan secara statistik signifikan, maka lebih lanjut dapat dihitung koefisien dari model autoregressive distributed lag, yang juga merupakan koefisien jangka panjang. dengan menggunakan rumus sebagai berikut:

Koefisien Jangka Panjang:

$$
\begin{aligned}
& \text { Konstanta }=\frac{\beta_{0}}{1-\beta_{5}}= \\
& \frac{-12,11855}{1-0,340476}=-17.8584 \\
& \text { BI Rate }=\frac{\beta_{3}+\beta_{5}}{1-\beta_{5}}= \\
& \frac{0,000626+0,340476}{1-0,340476}=0.517194 \\
& \text { Kurs }=\frac{\beta_{4}+\beta_{5}}{1-\beta_{5}}= \\
& \frac{1,342557+0,340476}{1-0,340476}=2.55189
\end{aligned}
$$

Berdasarkan hasil regresi diketahui bahwa variabel independen yaitu tingkat bunga dan kurs dalam jangka pendek berpengaruh secara signifikan terhadap perubahan IHSG, setiap perubahan 1\% pada perubahan kurs akan menyebabkan perubahan sebesar $1,38 \%$ pada IHSG dan setiap perubahan $1 \%$ pada Bi Rate akan menyebabkan $0,51 \%$ pada IHSG.Dalam jangka pendek variabel suku bunga mempunyai gerak berlawanan arah dengan gerak IHSG Ini ditandai dengan tanda koefisien yang negatif artinya ketika terjadi kenaikan pada tingkat suku bunga makan akan menurunkan IHSG begitu juga sebaliknya jika terjadi penurunan suku bunga maka akan menaikan IHSG, sedangkan variabel kurs mempunyai gerak searah dengan gerak IHSG Ini ditandai dengan tanda koefisien yang positif artinya ketika terjadi apresiasi mata uang rupiah maka akan meningkatkan kenaikan pada IHSG. Dan ketika terjadi depresiasi mata uang Rupiah maka akan menurunkan IHSG.

Sedangkan berdasarkan hasil perhitungan koefisien jangka panjang dari persamaan ECM di atas, maka dapat dikemukakan bahwa dalam jangka panjang setiap perubahan $1 \%$ pada perubahan kurs akan menyebabkan perubahan sebesar $2,55 \%$ pada IHSG dan setiap perubahan $1 \%$ pada Bi Rate akan menyebabkan $0,52 \%$ pada IHSG, walaupun pengaruh BI Rate tidak signifikan dalam jangka panjang.

\section{PENUTUP}

Model ini memberikan gambaran bahwa secara bersama-sama tingkat suku bunga BI Rate dan kurs dolar AS memberikan pengaruh yang signifikan. Begitu juga secara individual menyimpulkan bahwa tingkat suku bunga dan kurs dalam jangka pendek ternyata memberikan pengaruh yang signifikan terhadap Indeks Harga Saham Gabungan di BEI. Sedangkan dalam jangka panjang ternyata yang memberikan pengaruh yang signifikan terhadap Indeks Harga Saham Gabungan hanya kurs rupiah terhadap dolar saja sedangkan BI Rate pengaruhnya tidak signifikan. Pengaruh yang signifikan diberikan oleh kurs 
dolar AS dan arah pengaruhnya Positif artinya. ketika terjadi apresiasi mata uang rupiah maka akan meningkatkan kenaikan pada IHSG. Dan ketika terjadi depresiasi mata uang Rupiah maka akan menurunkan IHSG. Tidak signifikannya tingkat suku bunga karena pada periode penelitian, yaitu Juni 2008 sampai Agustus 2010 terjadi banyak sentimen diluar variabel yang diteliti. Faktor sentimen tersebut berasal darisituasi politik, ekonomi dan keamanan dalam negeri serta faktor kebijakan-kebijakan investasi. Misalnya di dalam bidang politik terjadinya Pemilihan umum baik legislatif maupun eksekutif, di bidang ekonomi adalah terjadinya krisis keuangan di Amerika Serikat, yang pengaruhnya hampir dirasakan oleh semua pasar keuangan dinegara-negara berkembang. Pengaruh dari variabelvariabel lain diluar variabel yang diteliti ( variabel residu) tersebut cukup besar kepada IHSG, yaitu sekitar $38 \%$.

Ada beberapa keterbatasan dalam penelitian ini, antara lain:Pertama, dari banyak faktor yang mempengaruhi IHSG BEI, peneliti hanya menggunakan dua variabel independen yaitu tingkat suku bunga BI Rate dan kurs dolar AS. Tentu saja, tidak hanya kedua faktor ini yang dapat mempengaruhi IHSG BEI, banyak faktor lain dari sisi ekonomi makro yang dapat mempengaruhi IHSG BEI. Namun karena satu dan lain hal, peneliti hanya menggunakan kedua variabel tersebut. Kedua, rentang waktu data penelitian yang hanya 27 bulan mungkin tidak mereprentasikan keadaan sesungguhnya, karena apabila rentang waktu diperpanjang kemungkinan dapat memberikan hasil penelitian yang secara signifikan berbeda dengan hasil penelitian ini.

\section{DAFTAR PUSTAKA}

Ajayi, R.A dan M. Mougoue. 1996. On The Dynamic Relation Between Stock Prices and Exchange Rate. Journal Of Finance Research. 19:193-207.

Dorbush, R. \& S. Fisher 1980. Exchange Rares and Current Acount. American Economic Review 70 960-71.

Frangkel, Jeffrey A. 1993. "Monetary and Portofolio-Balanced Model of the Determination of Exchange Rates" in Jeffrey A. Frankel on Exchange Rates Cambridge, MA: MIT Press

Gupta, Jyoti P., Alain Chevalier and Fran Sayekt. 2000. The Causality Between Interest Rate, Exchange Rate and Stock Price in Emerging Market: The Case Of The Jakarta Stock Exchange. Working Paper Series. EFMA 2000.Athens.

Lee, SB. 1992. Causal Relations Among Stock Return, Interest Rate, Real Activity, and Inflation. Journal Of Finance,47:1591-1603.

Mankiw, Gregory, 2007, Makroekonomi Edisi Keenam, Terjemahan: oleh Fitria Liza SE, \& Imam Nurmawam SE, Erlangga Jakarta

Muradoglu, G., Fatma Taskin, and like Bigan.2000. Causality Between Stock Returns and Macroeconomic Variables in Emerging Markets. Russian and East European Finance and Trade. 36:35-53. 
Sa'adah, Siti dan Yunia Panjaitan. 2006. Interaksi Dinamis Antara Harga Saham Dengan Nilai Tukar Rupiah Terhadap Dollar Amerika Serikat. Jurnal Ekonomi dan Bisnis.pp:46-62.

Sitinjak, Elyzabeth Lucky Maretha dan Widuri Kurniasari. 2003. Indikator- indikator Pasar Saham dan Pasar Uang Yang Saling Berkaitan Ditijau Dari Pasae Saham Sedang Bullish dan Bearish. Jurnal Riset Ekonomi dan Manajemen. Vol. 3 No. 3.

Sudjono. 2002. Analisis Keseimbangan dan Hubungan Simultan Antara Variabel Ekonomi Makro Terhadap Indeks Harga Saham di BEJ dengan Metode VAR (Vector Autoregression) dan ECM ( Error Correction Model). Jurnal Riset Ekonomi dan Manajemen. Vol. 2. no. 3.

Website Bank Indonesia. www.bi.go.id

Website finance indonesia.

www.financeindonesia.org

Website Jakarta Stock Exchange.

www.jsx.co.id

Widarjono, Agus.2005. Ekonometrika: Teori dan Aplikasi untuk Ekonomi dan Bisnis. Ekonosia FE UII Yogyakarta. 